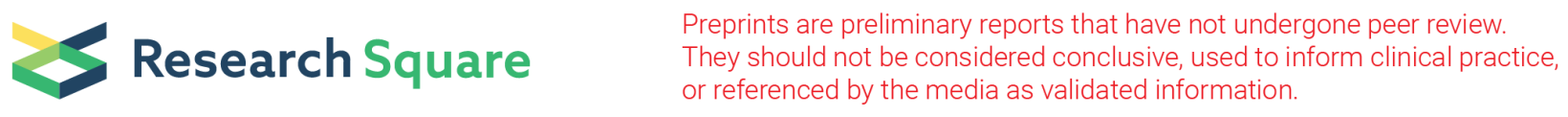

\title{
A Clinicopathologic Study of Malignancy in VCP-Associated Multisystem Proteinopathy
}

\author{
Alyaa Shmara \\ University of California Irvine \\ Kady Murphy \\ University of California Irvine \\ Mari Perez-Rosendahl \\ University of California Irvine \\ Ashley Kwon \\ University of California Irvine \\ Charles Smith \\ University of Kentucky \\ Virginia Kimonis ( $\nabla$ vkimonis@uci.edu) \\ University of California, Irvine https://orcid.org/0000-0003-1567-4449
}

\section{Research}

Keywords: Cancer, VCP, myopathy, Paget disease of bone, frontotemporal dementia, IBMPFD, multisystem proteinopathy, peripheral nerve sheath tumor, anaplastic pleomorphic xanthoastrocytoma, thymoma.

Posted Date: November 1st, 2021

DOI: https://doi.org/10.21203/rs.3.rs-986813/v1

License: (c) (1) This work is licensed under a Creative Commons Attribution 4.0 International License. Read Full License 


\title{
Abstract
}

\section{Background}

Valosin containing protein (VCP) is an important protein with many vital functions mostly related to the ubiquitin-proteasome system that provides protein quality control. VCP-associated inclusion body myopathy with Paget disease of bone and frontotemporal dementia (IBMPFD), also termed VCP disease and multisystem proteinopathy (MSP 1), is an autosomal dominant disorder caused by variants in the VCP gene on human chromosome 9 . VCP has also been strongly involved in cancer, with over-activity of VCP found in several cancers such as prostate, pancreatic, endometrial, esophageal cancers and osteosarcoma. Since MSP1 is caused by gain of function variants in the VCP gene, our hypothesis is that we would find an increased tendency of developing malignancies amongst our patients.

\section{Results}

Upon surveying 106 families with confirmed VCP variants, we found increased incidence of unusual tumors including malignant peripheral nerve sheath tumor, anaplastic pleomorphic xanthoastrocytoma and thymoma. Some of these cases developed cancer before displaying other classic VCP disease manifestations. We also present cases of common cancers; however, we did not find an increased incidence compared to the general population. This could be related to the early mortality associated with this disease.

\section{Conclusion}

This is the first study that expands the phenotype of VCP disease to potentially include unusual cancers and highlights the importance of further investigation of the role of $V C P$ in cancer development. The results of this study in VCP disease patients suggests that patients may be at an increased risk for unusual tumors.

\section{Background}

\author{
VCP disease
}

Inclusion body myopathy with Paget disease of bone and frontotemporal dementia (IBMPFD), also known as VCP disease and multisystem proteinopathy (MPS I), is an autosomal dominant hereditary disorder caused by variants in the valosin containing protein (VCP) gene on chromosome 9p13.3-12. The protein itself has several cellular functions, many pertaining to protein quality control and homeostasis [1]. Many of the specialized functions of VCP involve the ubiquitin-proteasome system (UPS) removing ubiquitinated substrates from cellular structures (including endoplasmic reticulum, mitochondria, endosomes, chromatin, and aggresomes) and unfolding them for degradation by the $26 \mathrm{~S}$ proteasome [1,2]. This function is especially evident in the endoplasmic reticulum associated degradation (ERAD) pathway. VCP is also required for autophagy through its role in autophagosome maturation which is disrupted in VCP disease [3]. The failure of proper VCP activity in the UPS and autophagy leads to protein aggregation. Other roles of VCP include those related to cell cycle progression, genomic stability, and membrane trafficking [4].

Mutations in the VCP gene consequently lead to protein aggregation, resulting in the many manifestations of VCP disease. Inclusion body myopathy (IBM), affecting $90 \%$ of patients, is characterized by proximal muscle weakness and atrophy involving the shoulder and hip girdle muscles with onset in the 30 s- 40 s. Skeletal muscle histology typically shows rimmed vacuoles and cytoplasmic ubiquitin and TAR DNA-binding protein 43 (TDP-43) positive inclusions [5]. Paget disease of bone (PDB) affects $42 \%$ of patients and typically manifests in the patient's 30 s [6]. The characteristics of PDB resulting from overactive osteoclasts include elevated serum alkaline phosphatase concentration and bone pain from involvement of the hip, spine, scapulae and skull [7]. Frontotemporal dementia (FTD) usually manifests in $32 \%$ of patients in their $50 \mathrm{~s}-60 \mathrm{~s}$. As the name implies, FTD results from degeneration of the frontal and temporal lobes of the brain. It is characterized by cognitive deficiencies, including difficulties with comprehension, dysnomia and dyscalculia in the early stages, auditory comprehension deficits, alexia, and agraphia in later stages. It also causes changes in personality and decision making [8]. We have previously reported 231 individuals carrying 15 different VCP variants in 36 families. Myopathy, PDB and FTD was present in $90 \%, 42 \%$ and $30 \%$ of the patients, respectively, beginning at an average age of 43,41 , and 56 years, respectively. Approximately $9 \%$ of patients with VCP variants had a classic amyotrophic lateral sclerosis (ALS) phenotype [6].

There is currently no cure or treatment for the myopathy and FTD associated with IBMPFD. PDB however can be treated with bisphosphonates which improve the pain and quality of life. Patients with IBMPFD generally die in their 50s or 60s due to respiratory failure or cardiac failure related to cardiomyopathy [9].

VCP variants

More than 60 variants in the $\mathrm{VCP}$ gene have been identified in patients, proposed to be gain of function variants, the most common variant being R155H [9]. Enhanced ATPase activity has been found in disease associated variants in $V C P[10]$. $V C P$ variants are also associated with amyotrophic lateral sclerosis (ALS) [11], Parkinson's disease [12], Huntington disease [13] and Charcot-Marie-Tooth disease type 2 [14].

VCP in cancer

It has been demonstrated that the expression level of VCP is significantly elevated in several different types of cancer, including non-small cell lung carcinomas, pancreatic endocrine neoplasms, and prostate cancer $[4,15,16]$. The overexpression of VCP has been associated with poor prognosis and increased metastasis, proving it valuable as a marker for the advancement of these cancers. The inhibition of VCP has been suggested as a treatment of metastasis in certain cancers [17]. Because gain of function variants in VCP are implicated in VCP disease, we hypothesize that an atypical distribution of malignancy types and a higher tendency to develop cancer may be found among our patients. 


\section{Methods}

Patient population and ethics

This retrospective study included individuals known to have cancer from a large cohort of 231 patients from 106 families with familial VCP variants. Those families were surveyed for unusual as well as common cancers. Written informed consent was obtained from all individuals. This study was approved by the University of California Irvine Institutional Review Board (IRB) (\#2009-1005). The study is also listed ClinicalTrials.gov (Identifier: NCT01353430).

Histological staining

Hematoxylin and Eosin (H\&E) and immunohistochemistry (IHC) staining was performed on tissue using standard protocols [5].

\section{Results}

The study included individuals known to have cancer from a large cohort of 231 patients from 106 families with familial VCP variants. We found unusual tumors in patients with VCP disease causing variants, some of whom presented with cancer prior to displaying classic VCP disease manifestations. These tumors include malignant peripheral nerve sheath tumor, anaplastic pleomorphic xanthoastrocytoma and thymoma.(Table 1)

Table 1

Clinical features of patients reported with VCP disease and malignancies

\begin{tabular}{|c|c|c|c|c|c|c|c|c|c|c|c|}
\hline Case & Cancer Type & $\begin{array}{l}\text { Current } \\
\text { Age y. } \\
\text { (Age } \\
\text { deceased) }\end{array}$ & Sex & $\begin{array}{l}\text { VCPvariant } \\
\text { (c.DNA;protein) }\end{array}$ & $\begin{array}{l}\text { Myopathy/ } \\
\text { Age of } \\
\text { onset y. }\end{array}$ & $\begin{array}{l}\text { PDB/ } \\
\text { Age } \\
\text { of } \\
\text { onset } \\
y .\end{array}$ & $\begin{array}{l}\text { FTD/Age } \\
\text { of onset } \\
y \text {. }\end{array}$ & $\begin{array}{l}\text { Cancer } \\
\text { age of } \\
\text { onset } \\
y \text {. }\end{array}$ & $\begin{array}{l}\text { Family History } \\
\text { of Cancer }\end{array}$ & $\begin{array}{l}\text { Incidence } \\
\text { in VCP } \\
\text { disease }\end{array}$ & $\begin{array}{l}\text { Incide } \\
\text { gener: } \\
\text { popul }\end{array}$ \\
\hline 1 & $\begin{array}{l}\text { Peripheral nerve } \\
\text { sheath tumor }\end{array}$ & 56 & M & $\begin{array}{l}\text { c. } 464 \mathrm{G}>\mathrm{A} \text {; } \\
\text { p.R155H }\end{array}$ & $+/ 36$ & $+/ 33$ & - & 45 & $\begin{array}{l}\text { Laryngeal } \\
\text { cancer }\end{array}$ & $1 / 231$ & $1 / 100$ \\
\hline 2 & $\begin{array}{l}\text { Pleomorphic } \\
\text { xanthoastrocytoma }\end{array}$ & (35) & M & $\begin{array}{l}\text { c. } 572 \mathrm{G}>\mathrm{A} \text {; } \\
\text { p.R191Q }\end{array}$ & - & - & - & 32 & - & $1 / 231$ & $<1 / 28$ \\
\hline 3 & Thymoma & (48) & $\mathrm{F}$ & $\begin{array}{l}\text { c. } 463 C>T ; \\
\text { p.R155C }\end{array}$ & $+/ 45$ & - & - & 30 & - & $1 / 231$ & $1 / 769$ \\
\hline 4 & $\begin{array}{l}\text { Breast invasive } \\
\text { ductal carcinoma }\end{array}$ & 76 & $\mathrm{~F}$ & $\begin{array}{l}\text { c. } 476 \mathrm{G}>\mathrm{A} \text {; } \\
\text { p.R159H }\end{array}$ & - & - & $+/ 71$ & 35 & - & $1 / 231$ & $1 / 8[5$ \\
\hline 5 & $\begin{array}{l}\text { Pancreatic ductal } \\
\text { adenocarcinoma }\end{array}$ & (55) & M & $\begin{array}{l}\text { c. } 463 C>T ; \\
\text { p.R155C }\end{array}$ & $+/ 50$ & $+/ 40$ & - & 54 & $\begin{array}{l}\text { Endometrial } \\
\text { adenocarcinoma }\end{array}$ & $1 / 231$ & $1 / 757$ \\
\hline 6 & $\begin{array}{l}\text { Endometrial } \\
\text { adenocarcinoma }\end{array}$ & $(60)$ & $\mathrm{F}$ & $\begin{array}{l}\text { c. } 463 C>T \\
\text { p.R155C }\end{array}$ & $+/ 34$ & $+/ 45$ & $+/ 59$ & 55 & $\begin{array}{l}\text { Pancreatic } \\
\text { ductal } \\
\text { adenocarcinoma }\end{array}$ & $1 / 231$ & $1 / 666$ \\
\hline 7 & $\begin{array}{l}\text { Prostate } \\
\text { adenocarcinoma }\end{array}$ & 72 & M & $\begin{array}{l}\text { c. } 464 \mathrm{G}>\mathrm{A} \text {; } \\
\text { p.R155H }\end{array}$ & $+/ 33$ & - & - & 69 & Renal cancer & $1 / 231$ & $1 / 14[6$ \\
\hline
\end{tabular}

$\mathrm{FTD}=$ frontotemporal dementia.

$\mathrm{PDB}=$ Paget disease of bone.

Case Reports

\section{Case 1}

A 45-year-old previously healthy male presented with right gluteal pain and was found to have a firm and painful swelling inferior to the gluteal muscle. An MRI scan of the gluteal and pelvic area showed a $9.7 \times 7.3 \times 18$ centimeter heterogeneously enhancing mass, deep to the right gluteus maximus in close proximity to the sciatic nerve (Figure 1). Needle biopsy revealed a neurofibroma with classic histology including spindle cells admixed with shredded carrot-like collagen in a myxoid stroma. Although the biopsy did not show features of malignancy, transformation to malignant peripheral nerve sheath tumor was suspected given the imaging features and very large size. Tumor resection contained areas of neurofibroma and revealed large areas of fascicular growth pattern with marked hypercellularity, mitotic activity (up to 4 mitoses in 10 high power fields) and Ki-67 proliferation index of 15\%. These findings confirmed transformation to a low grade malignant peripheral nerve sheath tumor (Figure 2). The patient responded well to post-operative adjuvant 3D conformal radiation therapy.

At age 47 years, he experienced right sided foot drop, numbness of the right leg with right calf atrophy which was attributed to right sciatic neuropathy occurring after tumor resection. Imaging showed no recurrent or residual tumor; however, EMG revealed widespread denervation in both lower extremities, indicating a more global neurological condition. Several of his siblings and his father were known to have the c.464G>A, p.R155H variant in the $V C P$ gene $[18$, 19] and he was confirmed to carry the familial VCP variant.

\section{Case 2}

A 32-year-old previously healthy male underwent a brain MRI for a research study which incidentally found an enhancing lesion in the left frontal lobe. MRI findings showed a $3.4 \mathrm{~cm}$ lobulated left posterior frontal mass with heterogeneous enhancement and surrounding edema causing a $2 \mathrm{~mm}$ midline shift (Figure 
3). Subsequently, he suffered a seizure and was treated with levetiracetam. A month later the patient underwent surgical resection which showed a glial neoplasm with pleomorphic epithelioid and spindled tumor cells, eosinophilic granular bodies and foci of lymphoplasmacytic inflammation, consistent with a pleomorphic xanthoastrocytoma (PXA). Anaplastic features were noted, including necrosis and an elevated Ki-67 proliferation index (Figure 4).

A postoperative MRI one month later showed post-surgical changes in the left frontal lobe with enhancement at the periphery of the surgical bed, which was favored to represent surgical changes and not residual tumor. After surgery he had no residual neurologic deficits and underwent radiation therapy receiving $1.8 \mathrm{~Gy}$ to $59.4 \mathrm{~Gy}$.

A brain MRI performed 5 months later revealed hemorrhage with residual nodular thickening along the periphery of the post-surgical bed. A year later, neuroimaging showed further tumor progression with an increasing amount of enhancing disease and FLAIR (fluid attenuated inversion recovery) changes. A second resection showed recurrent anaplastic PXA. Unfortunately, his post-operative MRI two months later showed return of nodular enhancement in the inner posterior superior aspect of the resection cavity, and subsequent scans showed further significant tumor progression.

He had two further resections and was treated with temozolomide followed by a combination of carmustine and bevacizumab chemotherapy for his progressive anaplastic PXA. Molecular testing of the tumor was positive for BRAF p.V600E (c.1799 T>A) variant. His treatment was changed to vemurafenib, a BRAF inhibitor along with bevacizumab [20] .

The patient had another seizure and began suffering from dysfluent speech with difficulty naming objects. Over the next month, the patient's aphasia worsened, and he suffered from additional breakthrough seizures and memory loss. Follow-up MRIs revealed marked increase in contrast enhancement that extended to involve the corpus callosum and the basal ganglia. His tumor grew $50 \%$ over the course of 5 weeks and was deemed inoperable, and radiation was not an option given prior heavy radiation, and the patient passed away at 35 years of age.

On review of his family history, his father passed away at the age of 67 years and his grandfather and his great uncle at age 69 , from myopathy and dementia. Of note, there was no family history of cancer. The patient was a known presymptomatic carrier of the c.572 G>A, p.R191Q variant of the $V C P$ gene [21] and did not manifest prior myopathy or Paget disease. However, the aphasia could potentially have been exacerbated by the $V C P$ variant.

\section{Case 3}

This female patient was diagnosed with thymoma with metastasis to both kidneys and lungs when she was 30 years old. She was treated with surgical excision and responded well to chemotherapy post-operatively. Although her history of thymoma put her at an increased risk of myasthenia gravis [22], a test for muscle-specific receptor tyrosine kinase antibodies and for acetylcholine receptor binding antibodies performed later at age 46 years was negative.

The onset of her symptoms began at age 45 years with lower back muscle weakness progressing to weakness of the leg muscles. At age 48 years, she was wheelchair-bound with quadriparesis and had severe dysarthria, which was diagnosed as generalized ALS. She progressed very rapidly and died three months after her diagnosis of ALS. Autopsy revealed extensive spinal motor neuron degeneration with loss of spinal anterior horn cells, gliosis and mislocalization of TDP-43 positive inclusions and Bunina bodies in the hypoglossal nucleus [23]

She had a known family history of VCP disease and was a known presymptomatic heterozygote carrier for the c.463C>T, p.R155C variant. On review of her family history, her father had myopathy and dementia, her brother and sister and daughter had progressive myopathy [24].

\section{Prevalence of common cancers in patients with VCP disease}

We performed a survey of cancers in our population cohort and did not find an increased incidence of common cancers. Here, we discuss the several common cancers that were also reported by patients.

\section{Case 4}

A 76-year-old female was diagnosed with an invasive ductal carcinoma of the breast at age 35 years. Since the tumor involved her entire right breast, she was treated with radical mastectomy, followed by chemotherapy and radiotherapy (Figure 5). Surgery revealed that tumor invasion was into the deep dermis with perineural infiltration. There was no axillary lymphatic tissue noted which was attributable to prior intense orthovoltage radiation at age one year following excision of a right axillary mass for which no medical records were available.

At the age of 71 years, the patient suffered from deteriorated behavioral and mental condition and was suspected to have Alzheimer's disease. She was later diagnosed with FTD associated with the $V C P$ c.476G $>A$, p.R159H variant previously reported in an Austrian family with VCP disease [25]. Her family history was significant for a brother who was diagnosed with IBM attributed to the same VCP variant. In addition, the patient's mother, aunt and older sister had already passed from dementia assumed to be FTD associated with VCP disease.

\section{Case 5}

A male patient was diagnosed with myopathy, PDB and type 2 diabetes mellitus at the age of 50 years and developed pancreatic cancer 4 years later. The patient's CT scan showed a heterogeneous $5.3 \mathrm{~cm}$. $\times 3.2 \mathrm{~cm}$. mass in the head and uncinate process of the pancreas that surrounded the superior mesenteric vein and invaded the portal vein, and also lesions in his liver and spleen. Biopsy of the pancreatic mass showed well-differentiated ductal adenocarcinoma. The patient was known to have the c.463C >T, p. R155C VCP variant. The patient's family history was significant for a brother with PDB, a father with myopathy, PDB and dementia, and several other family members with familial myopathy [24]. His sister, case 6 was diagnosed with endometrial cancer.

\section{Case 6}


A female patient with the c.463C>T, p. R155C variant developed distal myopathy at the age of 34 years which initially only affected her hands. This progressed to overall muscle weakness that resulted in frequent falls and trouble ambulating. By age 58 years, the patient was wheelchair-bound and had a Foley catheter.

She was diagnosed with endometrial adenocarcinoma at age 55 years after several months of experiencing postmenopausal bleeding. Endometrial biopsy showed invasive grade 2 endometrioid adenocarcinoma with myometrial invasion for which she underwent hysterectomy and received chemo and radiation therapy post-operatively. She died at age 60 years from complications of her underlying myopathy and dementia.

\section{Case 7}

A 72-year-old male first noted distal and proximal muscle weakness in his twenties. Muscle biopsy revealed rimmed vacuoles characteristic of IBM. There was no evidence of PDB or dementia. This patient was diagnosed with aggressive prostatic adenocarcinoma with metastatic adenopathy at age 69 years discovered by CT scan. The patient was not eligible for chemotherapy, radiotherapy, or surgery due to his debilitated state. Instead, he was started on androgen deprivation therapy with leuprolide and bicalutamide. Consequently, leuprolide was stopped due to the development of nausea and weakness, and treatment was continued with bicalutamide, which controlled tumor progression. The patient had the c.464G>A, p.R155H variant and displayed features of IBM as do several family members who have been previously reported [26, 27].

\section{Discussion}

Role of VCP in cancer

VCP has been involved in the DNA damage response through the identification of multiple chromatin-associated VCP substrates such as Ku70/80 and L3M6BTL1 for DNA double-strand breaks repair [28, 29] and CDT1 during DNA replication under normal and DNA-damaging conditions [30, 31]. A recent study has found that upon DNA damage, VCP undergoes phosphorylation at Ser ${ }^{784}$ in its C-terminal tail, leading to the selective increase of nuclear VCP activity with respect to chromatin-associated protein degradation. High levels of nuclear PSer $^{784}$-VCP are associated with poor outcome among patients with breast cancer who received genotoxic therapies. Thus, VCP plays an essential role in chromatin-associated protein clearance to such a degree that it is considered a 'genome caretaker' [32, 33].

VCP has also been shown to degrade $1 \mathrm{KBa}$, which is an inhibitor of the transcription factor NFKB, which when stimulated translocates into the nucleus and activates the expression of genes that stimulates cell growth, protecting the cells from apoptosis. Overexpression of the VCP gene correlates with constantly activated NFKB and may indeed promote cell proliferation and cell survival [4]. The NF-kB signaling pathway plays a key role in osteoclastogenesis and is well known to be a major player in PDB [34,35] and metastasis of osteosarcoma [36]. In vitro studies indicate that cells transfected with the A232E mutant VCP showed significantly higher clearance of IKBa and increased levels of NFKB compared to cells transfected with wild type VCP [37]. Thus, VCP variants cause inappropriate activation of the NF-kB signaling cascade and could contribute to the mechanism of pathogenesis in multiple tissues.

Recent evidence supports the concept that VCP acts as a regulator of cellular metabolism through its link to multiple metabolic processes in cancer cell lines and in patient-derived multiple myeloma cells. Cellular VCP dependency to maintain proteostasis was increased under conditions of glucose and glutamine limitation in a range of cancer cell lines. VCP maintains cancer cell metabolic and protein homoeostasis through its correlation with GCN2 (general control nonderepressible 2), a serine/threonine-protein amino acid-sensing kinase, that plays a key role in modulating amino acid metabolism as a response to nutrient deprivation [38].

Hypothesis for increased risk for cancer in VCP disease

It was hypothesized that VCP variants in patients may play a role in up-regulating the expression or activity of VCP, leading to an increased incidence of tumors in these patients. We indeed found that several patients were found to have unusual tumors.

Peripheral nerve sheath tumors are usually benign tumors that arise in peripheral nerves or extraneural soft tissue. Malignant peripheral nerve sheath tumors (MPNST) are uncommon and aggressive tumors that usually present in young or middle-aged adults and can either arise from a pre-existing neurofibroma or occur de novo. MPNST has a reported incidence of $0.001 \%$ in the general population [41]. In VCP disease however, the incidence is $0.433 \%$ which is higher than the reported $0.001 \%$. About $50 \%$ of MPNST are associated with an autosomal dominant variant in the neurofibromin 1 (NF1) gene that causes multiple neurofibromas: this variant leads to a loss of function in the tumor suppressor neurofibromin [39]. However, up to 47\% of MPNSTs develop sporadically [40]. Case 1 did not have any clinical features of NF1 apart from the tumor itself. This suggests that other pathways are implicated in neurofibroma transformation to aggressive MPNST. EGFR-STAT3 signaling pathway was found to promote such transformation to aggressive MPNST [41]. Interestingly, VCP promotes the growth, invasion, and metastasis of colorectal cancer through activation of STAT3 signaling [42].

Pleomorphic xanthoastrocytoma (PXA) is a rare type of brain cancer which most commonly affects children or young adults [43]. It is difficult to estimate the incidence of PXA in the general population since the incidence of anaplastic astrocytoma is 3.5 per million person/year [55]. This makes the incidence of PXA in VCP disease at 1/231 significantly higher than the general population. The diagnosis of anaplasia in PXA is based upon the presence of increased mitotic activity; however, the factors that drive progression to anaplastic PXA are not well-defined. Most PXAs harbor RAF alterations (most frequently BRAF V600E variant) plus homozygous deletion of the CDKN2A tumor suppressor, and anaplastic PXAs often also have TERT gene alterations [44].

Thymoma, likewise, is a rare type of cancer arising in thymic epithelial cells, usually presenting in a patient's 40 s or 50 s. The incidence of thymoma in the US is 0.13 per 100,000 person-year [56]. The incidence of thymoma of 1/231 in VCP disease is therefore significantly higher than the general population. 
Treatment involves surgery and adjuvant radiation because of its sensitivity to chemotherapy and radiation [45]. The early age of presentation in case 3 may be caused by the patient's $V C P$ variant.

Studies of thymoma reveal missense variant in the GTF21 gene on chromosome 7 c.74146970 T-A, with $82 \%$ prevalence in type A thymoma and $74 \%$ prevalence in type $\mathrm{AB}$ thymoma [46]. In thymic carcinomas, a type of cancer similar to thymoma, cancer gene variants in genes such as TP53 and CDKN2A have been identified [47]. Unfortunately, we were not able to obtain tissue from this patient because the tumor occurred over 20 years ago.

We also reported other cases of cancer in our cohort of 231 patients with VCP disease in which the incidence of common cancers was not higher than the general population. This might be explained by the short life span of VCP disease patients since they die from respiratory or cardiac failure [6]. Case 4 presented with aggressive breast cancer at an early age without a positive family history of breast cancer. Although breast cancer risk is increased in women treated for childhood cancer with radiation applied to a broad field of breast tissue [48], we believe that the aggressive breast tumor in case 4 was possibly exacerbated by her VCP variant. One study reported that VCP expression levels in breast tumors correlates with the TNM stage used to describe the amount and spread of cancer (T represents tumor size and spread into nearby tissue; N: cancer spread to nearby lymph nodes; and M: metastasis), and Ki67 proliferation marker. Compared to normal mammary epithelial cells, the expression of VCP was significantly higher in the cytoplasm of breast cancer cells. Interestingly, patients with high levels of VCP expression had poorer overall survival; therefore, VCP expression is suggested as an independent prognostic factor in breast carcinoma [49].

Up-regulation of VCP in association with IBMPFD and with cancer

Using E-coli Rosetta cells to induce expression of disease-related VCP variant, a study found that all the mutants had increased ATPase activity compared to those of the wild type [10]. The A232E variant, which correlates to the most severe disease phenotype [24], showed the highest increase of activity out of all the variants tested. Thus, $V C P$ variants can have a significant impact on VCP-related pathways involving ATPase activity.

It has been well-documented that VCP is overexpressed in multiple types of cancers and has been suggested as a marker for prognosis. However, it has not been shown why VCP is overexpressed in these tumors or the effects of its overexpression. Given that VCP has many different roles in the cell, including those in cell death and homeostasis, it may be challenging to identify exactly how overexpressed VCP functions differently in tumors.

Although its exact role in cancer activity remains unknown, it has been shown that VCP inhibitors can result in cancer cell death, suggesting the possible use of VCP inhibition as a potential cancer therapy $[39,50]$. One potent and specific VCP inhibitor called NMS-873 was able to activate the unfolded protein response and thus interfered with autophagy, resulting in cancer cell death [50]. Another potent and specific VCP inhibitor called CB-5083, which is orally bioavailable, is responsible for causing modulation in VCP related pathways, resulting in apoptosis and antitumor activity [51].

In the case of ovarian cancer specifically, $V C P$ has been found to be an essential gene in cell lineages, and a study showed that ovarian cancer was sensitive to VCP inhibition. The same study showed that modification of ER stress by agents could enhance the cytotoxic activity of VCP inhibitors in treating ovarian cancer [52].

Rationale for the association of unusual tumors in VCP disease

With experimental evidence of the up-regulation of ATPase activity in VCP disease causing variants, we propose that the VCP variant may be a key factor in the pathogenesis of these uncommon cancers, since $V C P$ has been shown to be overexpressed in several different cancers. Targeting VCP as a potential cancer treatment has been an effective method in multiple studies [35, 46-48]. In 1990, Fearon and Vogelstein proposed a model of colorectal carcinoma resulting from variants in salient genes, including the inactivation of tumor suppressor genes and the activation of oncogenes. Accumulation of these mutations happens sequentially, with mutations of some genes preceding that of others, this process takes place over several years before the cancer develops [53]. Because patients with VCP disease have a shorter life span attributable to respiratory muscle weakness and cardiomyopathy [54], the incidence of reported cancers is predicted to be lower than the general population which was the case for common cancers. Nevertheless, we found unusual tumors that occurred earlier and appeared to be more aggressive in our cohort of patients with VCP disease. Since cancer is associated with overexpression of VCP, and the disease is associated with gain of function variants in the VCP gene, it is predicted that VCP inhibitors potentially would be effective for treatment of both disorders.

\section{Conclusion}

Expression of $V C P$ in cancers has been correlated with tumor aggressiveness and prognosis. However, the underlying molecular mechanism is unclear. Based on the evidence for a strong relationship between cancer and VCP function, and up-regulation of VCP activity caused by IBMPFD-related VCP variants, we conducted this study to characterize cancers in this group of patients. The results of this study in VCP disease patients suggests that patients may be at an increased risk for cancer, especially for unusual tumors. This suggests that cancer patients with gain of function VCPvariants may potentially be more effectively treated with VCP inhibitors. A potential topic of future research would be to further study the molecular mechanisms implicating VCP in human cancer cells.

\section{Declarations}

\section{Ethics approval and consent to participate}

Written informed consent was obtained from all individuals. This study was approved by the University of California Irvine Institutional Review Board (IRB) (\#2007-5832). The study is also listed ClinicalTrials.gov (Identifier: NCT01353430). 


\section{Consent for publication}

Written informed consent was obtained from all the subjects included in the study. In the case of deceased patients, they provided their consents prior to their demise.

\section{Authors' contributions}

Virginia Kimonis: Conceptualization, methodology, resources, supervision, validation, project administration and funding acquisition.

Alyaa Shmara: Investigation, writing - original draft, visualization and validation.

Kady Murphy: Investigation, writing - original draft, data curation, visualization.

Mari Perez-Rosendahl: Validation, writing and resources.

Ashley Kwon: Investigation, writing - original draft, and data curation.

Charles Smith: Validation, resources, and funding acquisition.

All authors read and approved the final manuscript.

\section{Competing interests}

The authors declare that they have no competing interests.

\section{Funding}

This work was supported by the National Institutes of Health [grant number AR050236, R01 and R56], and the AG025159 to CS.

\section{Acknowledgements}

We would like to thank Abhilasha Surampalli, Kajal Bawa and Emily Chien for their contribution to this work. We would like to thank the patients and their health care providers for their contribution to this manuscript.

\section{Availability of data and materials}

The datasets generated during and/or analyzed during the current study are available

from the corresponding author on reasonable request.

\section{References}

1. Meyer H, Weihl CC. The VCP/p97 system at a glance: connecting cellular function to disease pathogenesis. Journal of Cell Science 2014;127:3877.

2. Meyer H, Bug M, Bremer S. Emerging functions of the VCP/p97 AAA-ATPase in the ubiquitin system. Nature cell biology 2012;14:117-23.

3. Ju J-S, Fuentealba RA, Miller SE, Jackson E, Piwnica-Worms D, Baloh RH, Weihl CC. Valosin-containing protein (VCP) is required for autophagy and is disrupted in VCP disease. Journal of Cell Biology 2009;187:875-88.

4. Fessart D, Marza E, Taouji S, Delom F, Chevet E. P97/CDC-48: proteostasis control in tumor cell biology. Cancer Lett 2013;337:26-34.

5. Weihl CC, Pestronk A, Kimonis VE. Valosin-containing protein disease: inclusion body myopathy with Paget's disease of the bone and fronto-temporal dementia. Neuromuscul Disord 2009;19:308-15.

6. Al-Obeidi E, Al-Tahan S, Surampalli A, Goyal N, Wang AK, Hermann A, Omizo M, Smith C, Mozaffar T, Kimonis V. Genotype-phenotype study in patients with valosin-containing protein mutations associated with multisystem proteinopathy. Clinical genetics 2018;93:119-25.

7. Farpour F, Tehranzadeh J, Donkervoort S, Smith C, Martin B, Vanjara P, Osann K, Kimonis VE. Radiological features of Paget disease of bone associated with VCP myopathy. Skeletal Radiology 2012;41:329-37.

8. Kimonis V. Inclusion Body Myopathy with Paget Disease of Bone and/or Frontotemporal Dementia. In: Adam MP, Ardinger HH, Pagon RA, Wallace SE, Bean LJH, Stephens K, Amemiya A, editors. GeneReviews(®). Seattle (WA): University of Washington, Seattle Copyright ( $1993-2020$, University of Washington, Seattle. GeneReviews is a registered trademark of the University of Washington, Seattle. All rights reserved., 1993.

9. Evangelista T, Weihl CC, Kimonis V, Lochmüller H, Clemen C, Deshaies R, Evangelista T, Eymard B, Greensmith L, Hilton-Jones D, Kimonis V, Kley R, Lochmüller H, Meyer H, Mozaffar T, Noguchi S, Ralston S, Ridha B, Udd B, Weihl C, Brumhard M, Brumhard S. 215th ENMC International Workshop VCPrelated multi-system proteinopathy (IBMPFD) 13-15 November 2015, Heemskerk, The Netherlands. Neuromuscular Disorders 2016;26:535-47.

10. Niwa H, Ewens CA, Tsang C, Yeung HO, Zhang X, Freemont PS. The role of the N-domain in the ATPase activity of the mammalian AAA ATPase p97/VCP. The Journal of biological chemistry 2012;287:8561-70.

11. Johnson JO, Mandrioli J, Benatar M, Abramzon Y, Van Deerlin VM, Trojanowski JQ, Gibbs JR, Brunetti M, Gronka S, Wuu J, Ding J, McCluskey L, MartinezLage M, Falcone D, Hernandez DG, Arepalli S, Chong S, Schymick JC, Rothstein J, Landi F, Wang Y-D, Calvo A, Mora G, Sabatelli M, Monsurrò MR, Battistini S, Salvi F, Spataro R, Sola P, Borghero G, Consortium I, Galassi G, Scholz SW, Taylor JP, Restagno G, Chiò A, Traynor BJ. Exome sequencing reveals VCP mutations as a cause of familial ALS. Neuron 2010;68:857-64.

Page 7/11 
12. Chan N, Le C, Shieh P, Mozaffar T, Khare M, Bronstein J, Kimonis V. Valosin-containing protein mutation and Parkinson's disease. Parkinsonism Relat Disord 2012;18:107-9.

13. Mariani L-L, Tesson C, Charles P, Cazeneuve C, Hahn V, Youssov K, Freeman L, Grabli D, Roze E, Noël S, Peuvion J-N, Bachoud-Levi A-C, Brice A, Stevanin G, Durr A. Expanding the Spectrum of Genes Involved in Huntington Disease Using a Combined Clinical and Genetic Approach. JAMA Neurology 2016;73:1105-14.

14. Gonzalez MA, Feely SM, Speziani F, Strickland AV, Danzi M, Bacon C, Lee Y, Chou T-F, Blanton SH, Weihl CC, Zuchner S, Shy ME. A novel mutation in VCP causes Charcot-Marie-Tooth Type 2 disease. Brain: a journal of neurology 2014;137:2897-902.

15. Valle CW, Min T, Bodas M, Mazur S, Begum S, Tang D, Vij N. Critical Role of VCP/p97 in the Pathogenesis and Progression of Non-Small Cell Lung Carcinoma. PloS one 2011;6:e29073.

16. Duscharla D, Reddy Kami Reddy K, Dasari C, Bhukya S, Ummanni R. Interleukin-6 induced overexpression of valosin-containing protein (VCP)/p97 is associated with androgen-independent prostate cancer (AIPC) progression. Journal of cellular physiology 2018;233:7148-64.

17. Long XH, Zhang ZH, Liu ZL, Huang SH, Luo QF. Inhibiting valosin-containing protein suppresses osteosarcoma cell metastasis via AKT/nuclear factor of kappa B signaling pathway in vitro. Indian journal of pathology \& microbiology 2013;56:190-5.

18. Kimonis VE, Kovach MJ, Waggoner B, Leal S, Salam A, Rimer L, Davis K, Khardori R, Gelber D. Clinical and molecular studies in a unique family with autosomal dominant limb-girdle muscular dystrophy and Paget disease of bone. Genetics in medicine: official journal of the American College of Medical Genetics 2000;2:232-41.

19. Kovach MJ, Waggoner B, Leal SM, Gelber D, Khardori R, Levenstien MA, Shanks CA, Gregg G, Al-Lozi MT, Miller T, Rakowicz W, Lopate G, Florence J, Glosser G, Simmons Z, Morris JC, Whyte MP, Pestronk A, Kimonis VE. Clinical delineation and localization to chromosome 9p13.3-p12 of a unique dominant disorder in four families: hereditary inclusion body myopathy, Paget disease of bone, and frontotemporal dementia. Mol Genet Metab 2001;74:458-75.

20. Lukas RV, Merrell RT. BRAF inhibition with concomitant tumor treating fields for a multiply progressive pleomorphic xanthoastrocytoma. CNS Oncol 2018;7:CNS10-CNS.

21. Mehta SG, Khare M, Ramani R, Watts GD, Simon M, Osann KE, Donkervoort S, Dec E, Nalbandian A, Platt J, Pasquali M, Wang A, Mozaffar T, Smith CD, Kimonis VE. Genotype-phenotype studies of VCP-associated inclusion body myopathy with Paget disease of bone and/or frontotemporal dementia. Clinical genetics 2013;83:422-31.

22. Riedel RF, Burfeind Jr WR. Thymoma: Benign Appearance, Malignant Potential. The Oncologist 2006;11:887-94.

23. Surampalli A NA, Donkervoort S, Khare M, Wang AK, et al.. A Clinicopathologic Case Report of a Female with Valosin-Containing Protein (VCP) Gene Mutation Related Disease. International Journal of Neurodegenerative Disorders 2018;1:1-006.

24. Watts GDJ, Wymer J, Kovach MJ, Mehta SG, Mumm S, Darvish D, Pestronk A, Whyte MP, Kimonis VE. Inclusion body myopathy associated with Paget disease of bone and frontotemporal dementia is caused by mutant valosin-containing protein. Nature genetics 2004;36:377-81.

25. Haubenberger D, Bittner RE, Rauch-Shorny S, Zimprich F, Mannhalter C, Wagner L, Mineva I, Vass K, Auff E, Zimprich A. Inclusion body myopathy and Paget disease is linked to a novel mutation in the VCP gene. Neurology 2005;65:1304-5.

26. Kimonis VE, Mehta SG, Fulchiero EC, Thomasova D, Pasquali M, Boycott K, Neilan EG, Kartashov A, Forman MS, Tucker S, Kimonis K, Mumm S, Whyte MP, Smith CD, Watts GD. Clinical studies in familial VCP myopathy associated with Paget disease of bone and frontotemporal dementia. American journal of medical genetics Part A 2008;146A:745-57.

27. Watts GD, Wymer J, Kovach MJ, Mehta SG, Mumm S, Darvish D, Pestronk A, Whyte MP, Kimonis VE. Inclusion body myopathy associated with Paget disease of bone and frontotemporal dementia is caused by mutant valosin-containing protein. Nature genetics 2004;36:377-81.

28. Acs K, Luijsterburg MS, Ackermann L, Salomons FA, Hoppe T, Dantuma NP. The AAA-ATPase VCP/p97 promotes 53 BP1 recruitment by removing L3MBTL1 from DNA double-strand breaks. Nature structural \& molecular biology 2011;18:1345-50.

29. van den Boom J, Wolf M, Weimann L, Schulze N, Li F, Kaschani F, Riemer A, Zierhut C, Kaiser M, Iliakis G, Funabiki H, Meyer H. VCP/p97 Extracts Sterically Trapped Ku70/80 Rings from DNA in Double-Strand Break Repair. Molecular cell 2016;64:189-98.

30. Franz A, Orth M, Pirson PA, Sonneville R, Blow JJ, Gartner A, Stemmann O, Hoppe T. CDC-48/p97 coordinates CDT-1 degradation with GINS chromatin dissociation to ensure faithful DNA replication. Mol Cell 2011;44:85-96.

31. Raman M, Havens CG, Walter JC, Harper JW. A genome-wide screen identifies p97 as an essential regulator of DNA damage-dependent CDT1 destruction. Mol Cell 2011;44:72-84.

32. Zhu C, Rogers A, Asleh K, Won J, Gao D, Leung S, Li S, Vij KR, Zhu J, Held JM, You Z, Nielsen TO, Shao J. Phospho-Ser(784)-VCP Is Required for DNA Damage Response and Is Associated with Poor Prognosis of Chemotherapy-Treated Breast Cancer. Cell Rep 2020;31:107745-.

33. Livingstone M, Ruan H, Weiner J, Clauser KR, Strack P, Jin S, Williams A, Greulich H, Gardner J, Venere M, Mochan TA, DiTullio RA, Jr., Moravcevic K, Gorgoulis VG, Burkhardt A, Halazonetis TD. Valosin-containing protein phosphorylation at Ser784 in response to DNA damage. Cancer research 2005;65:7533-40.

34. Daroszewska A, Ralston SH. Mechanisms of disease: genetics of Paget's disease of bone and related disorders. Nature clinical practice Rheumatology 2006;2:270-7.

35. Ralston SH, Taylor JP. Rare Inherited forms of Paget's Disease and Related Syndromes. Calcif Tissue Int 2019;104:501-16.

36. Asai T, Tomita Y, Nakatsuka S, Hoshida Y, Myoui A, Yoshikawa H, Aozasa K. VCP (p97) regulates NFkappaB signaling pathway, which is important for metastasis of osteosarcoma cell line. Japanese journal of cancer research: Gann 2002;93:296-304. 
37. Custer SK, Neumann M, Lu H, Wright AC, Taylor JP. Transgenic mice expressing mutant forms VCP/p97 recapitulate the full spectrum of IBMPFD including degeneration in muscle, brain and bone. Human Molecular Genetics 2010;19:1741-55.

38. Parzych K, Saavedra-García P, Valbuena GN, Al-Sadah HA, Robinson ME, Penfold L, Kuzeva DM, Ruiz-Tellez A, Loaiza S, Holzmann V, Caputo V, Johnson DC, Kaiser MF, Karadimitris A, Lam EWF, Chevet E, Feldhahn N, Keun HC, Auner HW. The coordinated action of VCP/p97 and GCN2 regulates cancer cell metabolism and proteostasis during nutrient limitation. Oncogene 2019;38:3216-31.

39. Farid M, Demicco EG, Garcia R, Ahn L, Merola PR, Cioffi A, Maki RG. Malignant Peripheral Nerve Sheath Tumors. The Oncologist 2014;19:193-201.

40. Watson KL, Al Sannaa GA, Kivlin CM, Ingram DR, Landers SM, Roland CL, Cormier JN, Hunt KK, Feig BW, Ashleigh Guadagnolo B, Bishop AJ, Wang W-L, Slopis JM, McCutcheon IE, Lazar AJ, Torres KE. Patterns of recurrence and survival in sporadic, neurofibromatosis Type 1-associated, and radiationassociated malignant peripheral nerve sheath tumors. J Neurosurg 2017;126:319-29.

41. Wu J, Patmore DM, Jousma E, Eaves DW, Breving K, Patel AV, Schwartz EB, Fuchs JR, Cripe TP, Stemmer-Rachamimov AO, Ratner N. EGFR-STAT3 signaling promotes formation of malignant peripheral nerve sheath tumors. Oncogene 2014;33:173-80.

42. Fu Q, Jiang Y, Zhang D, Liu X, Guo J, Zhao J. Valosin-containing protein (VCP) promotes the growth, invasion, and metastasis of colorectal cancer through activation of STAT3 signaling. Molecular and Cellular Biochemistry 2016;418:189-98.

43. Ida CM, Rodriguez FJ, Burger PC, Caron AA, Jenkins SM, Spears GM, Aranguren DL, Lachance DH, Giannini C. Pleomorphic Xanthoastrocytoma: Natural History and Long-Term Follow-Up. Brain Pathol 2015;25:575-86.

44. Phillips JJ, Gong H, Chen K, Joseph NM, van Ziffle J, Bastian BC, Grenert JP, Kline CN, Mueller S, Banerjee A, Nicolaides T, Gupta N, Berger MS, Lee HS, Pekmezci M, Tihan T, Bollen AW, Perry A, Shieh JTC, Solomon DA. The genetic landscape of anaplastic pleomorphic xanthoastrocytoma. Brain Pathol 2019;29:85-96.

45. Jackson MW, Palma DA, Camidge DR, Jones BL, Robin TP, Sher DJ, Koshy M, Kavanagh BD, Gaspar LE, Rusthoven CG. The Impact of Postoperative Radiotherapy for Thymoma and Thymic Carcinoma. Journal of Thoracic Oncology 2017;12:734-44.

46. Petrini I, Meltzer PS, Kim I-K, Lucchi M, Park K-S, Fontanini G, Gao J, Zucali PA, Calabrese F, Favaretto A, Rea F, Rodriguez-Canales J, Walker RL, Pineda M, Zhu YJ, Lau C, Killian KJ, Bilke S, Voeller D, Dakshanamurthy S, Wang Y, Giaccone G. A specific missense mutation in GTF2I occurs at high frequency in thymic epithelial tumors. Nature genetics 2014;46:844-9.

47. Enkner F, Pichlhöfer B, Zaharie AT, Krunic M, Holper TM, Janik S, Moser B, Schlangen K, Neudert B, Walter K, Migschitz B, Müllauer L. Molecular Profiling of Thymoma and Thymic Carcinoma: Genetic Differences and Potential Novel Therapeutic Targets. Pathol Oncol Res 2017;23:551-64.

48. Moskowitz CS, Chou JF, Wolden SL, Bernstein JL, Malhotra J, Novetsky Friedman D, Mubdi NZ, Leisenring WM, Stovall M, Hammond S, Smith SA, Henderson TO, Boice JD, Hudson MM, Diller LR, Bhatia S, Kenney LB, Neglia JP, Begg CB, Robison LL, Oeffinger KC. Breast cancer after chest radiation therapy for childhood cancer. J Clin Oncol 2014;32:2217-23.

49. Cui Y, Niu M, Zhang X, Zhong Z, Wang J, Pang D. High expression of valosin-containing protein predicts poor prognosis in patients with breast carcinoma. Tumor Biology 2015;36:9919-27.

50. Magnaghi P, D'Alessio R, Valsasina B, Avanzi N, Rizzi S, Asa D, Gasparri F, Cozzi L, Cucchi U, Orrenius C, Polucci P, Ballinari D, Perrera C, Leone A, Cervi G, Casale E, Xiao Y, Wong C, Anderson DJ, Galvani A, Donati D, O'Brien T, Jackson PK, Isacchi A. Covalent and allosteric inhibitors of the ATPase VCP/p97 induce cancer cell death. Nature Chemical Biology 2013;9:548-56.

51. Anderson DJ, Le Moigne R, Djakovic S, Kumar B, Rice J, Wong S, Wang J, Yao B, Valle E, Kiss von Soly S, Madriaga A, Soriano F, Menon M-K, Wu ZY, Kampmann M, Chen Y, Weissman JS, Aftab BT, Yakes FM, Shawver L, Zhou H-J, Wustrow D, Rolfe M. Targeting the AAA ATPase p97 as an Approach to Treat Cancer through Disruption of Protein Homeostasis. Cancer Cell 2015;28:653-65.

52. Bastola P, Neums L, Schoenen FJ, Chien J. VCP inhibitors induce endoplasmic reticulum stress, cause cell cycle arrest, trigger caspase-mediated cell death and synergistically kill ovarian cancer cells in combination with Salubrinal. Molecular Oncology 2016;10:1559-74.

53. Fearon ER, Vogelstein B. A genetic model for colorectal tumorigenesis. Cell 1990;61:759-67.

54. Bayraktar O, Oral O, Kocaturk NM, Akkoc Y, Eberhart K, Kosar A, Gozuacik D. IBMPFD Disease-Causing Mutant VCP/p97 Proteins Are Targets of Autophagic-Lysosomal Degradation. PloS one 2016;11:e0164864-e.

55. Smoll NR, Hamilton B. Incidence and relative survival of anaplastic astrocytomas. Neuro Oncol. 2014;16(10):1400-1407. doi:10.1093/neuonc/nou053

56. Engels EA. Epidemiology of thymoma and associated malignancies. J Thorac Oncol. 2010 Oct;5(10 Suppl 4):S260-5. doi: 10.1097/JTO.0b013e3181f1f62d. PMID: 20859116; PMCID: PMC2951303.

57. U.S. Breast Cancer Statistics [Internet]. Breastcancer.org. 2021 [cited 20210ct17]. Available from: https://www.breastcancer.org/symptoms/understand_bc/statistics

58. Cancer of the pancreas - cancer stat facts [Internet]. SEER. [cited 20210ct17]. Available from: https://seer.cancer.gov/statfacts/html/pancreas.html 59. Diet and cancer report [Internet]. WCRF International. 2021 [cited 20210ct17]. Available from: https://www.wcrf.org/diet-and-cancer/

60. Bray, F., Ferlay, J., Soerjomataram, I., Siegel, R.L., Torre, L.A. and Jemal, A. (2018), Global cancer statistics 2018: GLOBOCAN estimates of incidence and mortality worldwide for 36 cancers in 185 countries. CA: A Cancer Journal for Clinicians, 68: 394-424. https://doi.org/10.3322/caac.21492

\section{Figures}




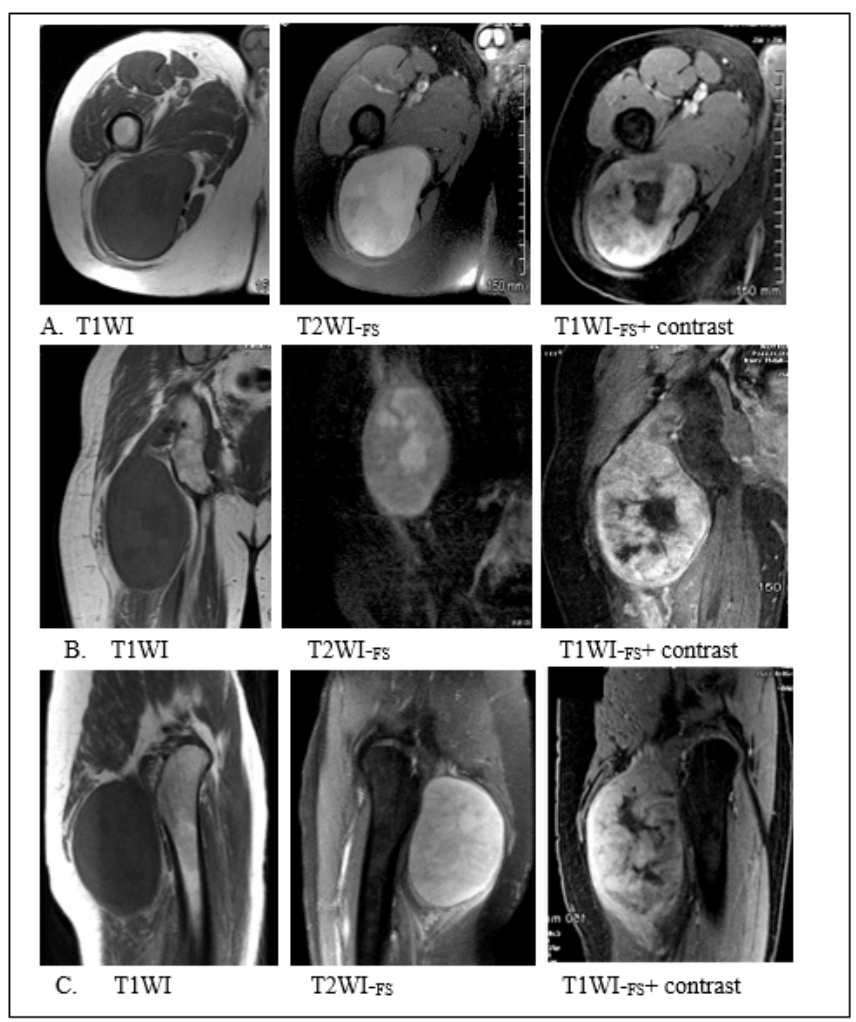

Figure 1

Case $1 \mathrm{MRI}$ of the gluteal and pelvic area. Imaging displays a large heterogeneous enhancing mass in the posterior lateral soft tissues of the right gluteal region. Low-grade peripheral nerve sheath tumor deep to the right gluteus maximus. A-Axial B. Coronal C. Sagittal MRI. T1WI= T1 weighted image. T2WI-FS = T2 weighted, fat-suppressed. T1WI-FS+ contrast= T1 weighted, fat suppressed with contrast.

展

\section{Figure 2}

Histologic features of tumor resection from right gluteal region of Case 1. Section showing low-grade malignant peripheral nerve sheath tumor with hypercellular fascicles of mitotically active (arrows) spindle cells with enlarged hyperchromatic nuclei. (H\&E, 200x).
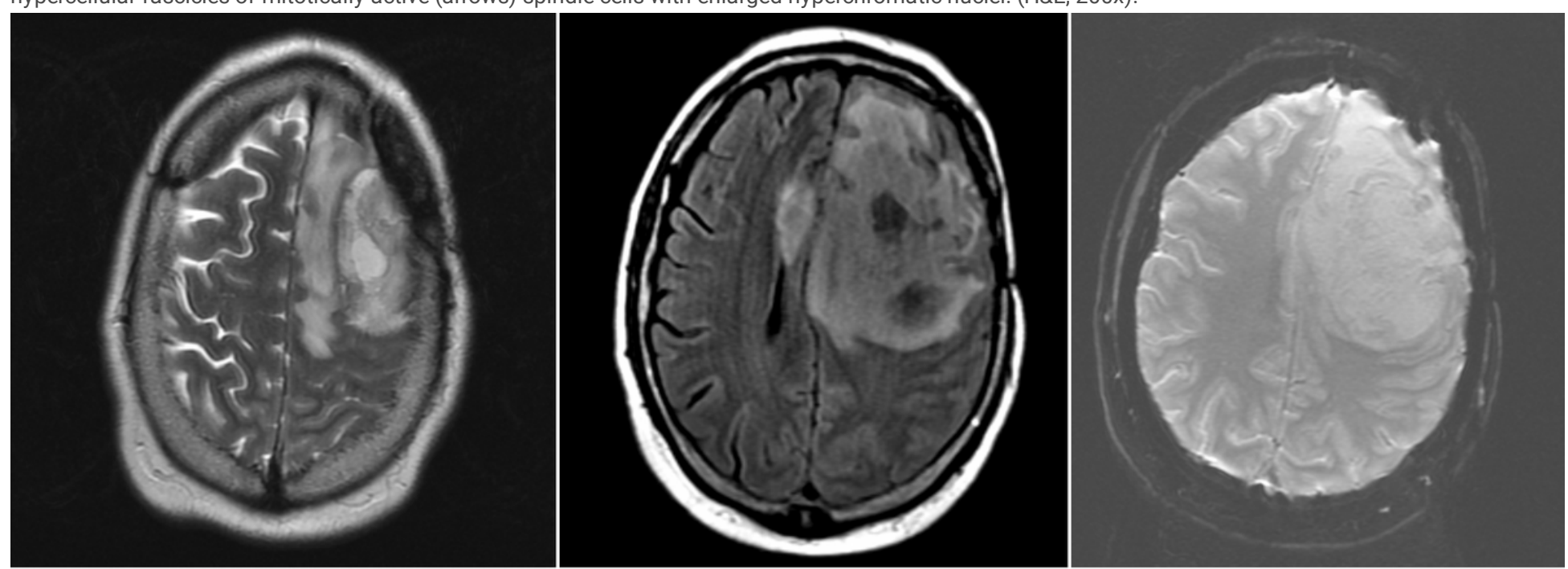

A. $\mathrm{T} 2 \mathrm{~W}$

B. FLAIR

C. SWI 
Case 2 brain MRI axial plane. Imaging shows lobulated heterogeneous solid left posterior frontal mass with foci of internal hemorrhage and surrounding edema causing significant mass effect and mild to moderate midline shift. A. T2WI= T2 weighted image. B. FLAIR= Fluid attenuated inversion recovery. C. SWI= Susceptibility weighted imaging.

2

\section{Figure 4}

Histologic features of tumor resection from left posterior frontal lobe of Case 2. Anaplastic pleomorphic xanthoastrocytoma composed of epithelioid glial cells with minimal pleomorphism (A) (H\&E, 200x). Anaplastic features include less pleomorphism than is typical for low grade PXA, areas of necrosis (not pictured), and increased proliferation evidenced by Ki-67 (B) (Immunohistochemistry for Ki-67, 200x).

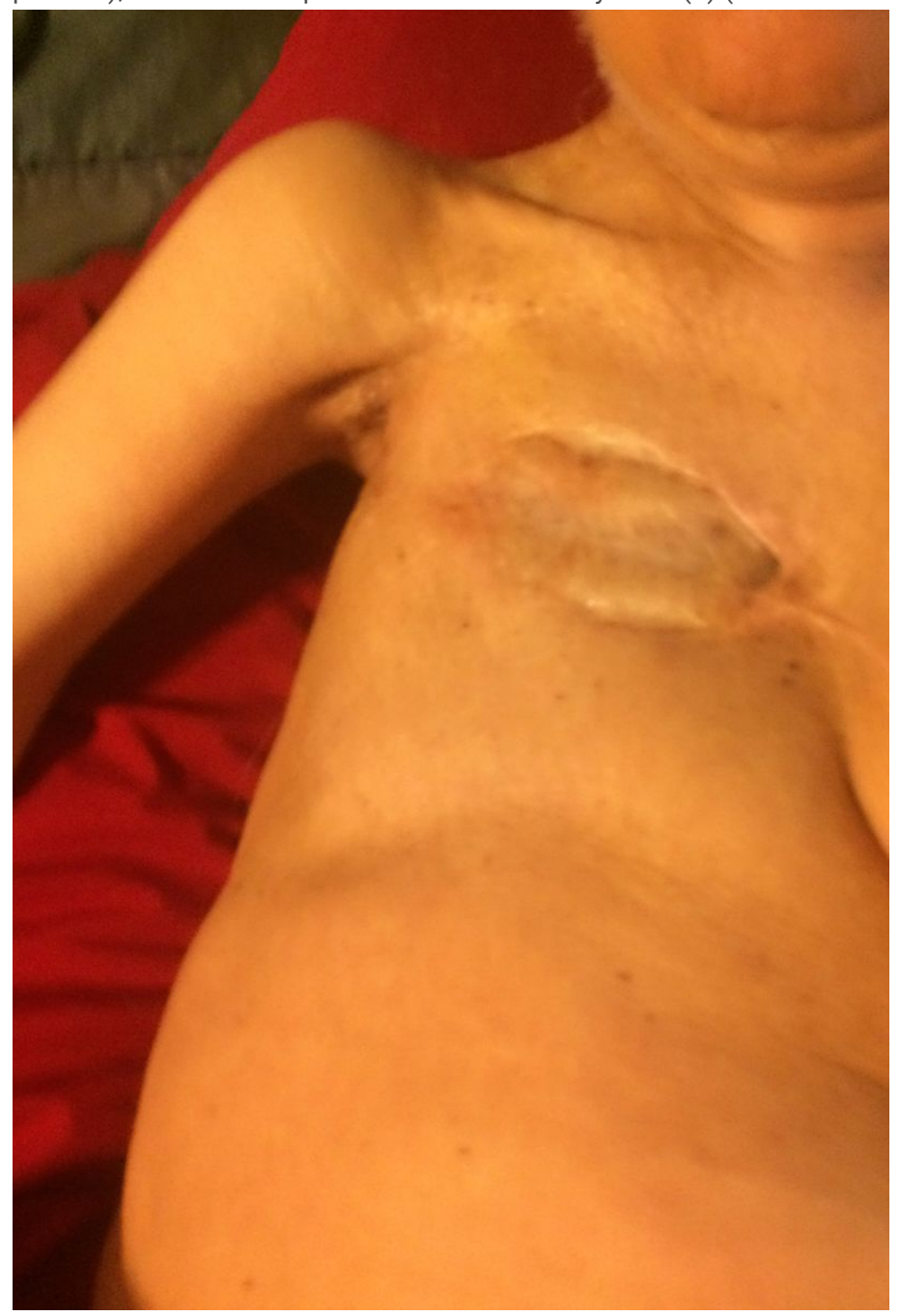

\section{Figure 5}

Chest of Case 4 at age 76 years. Chest photograph 41 years after radical mastectomy shows severe atrophy of pectoralis major muscle dating from irradiation in childhood. 